\title{
Publishing Photograph That Had "Gone Viral" Ruled Copyright Infringement: Otto v. Hearst Publications, Inc.
}

\author{
Vincent Peppe \\ Belmont University \\ This paper was presented at the 2019 International Summit of the \\ Music \& Entertainment Industry Educators Association \\ March 21-23, 2019
}

https://doi.org/10.25101/19.31

\section{Abstract}

In June 2017, James Otto attended a friend's wedding at the Trump National Golf Course in Bedminster, New Jersey. To the surprise of the newlyweds and their guests, President Trump crashed the reception. The president posed for photographs with the newlyweds and lingered to sign autographs. Otto took a photo on his iPhone of the president and the bride. He texted the photo to his friend, Sean Burke, another guest at the wedding. Burke texted the photo to Linda Piatowski, a relative of the bride, who posted it on Instagram. By the next morning, the image had gone viral, appearing on the websites of TMZ, CNN, the Washington Post, the Daily Mail, and Esquire, owned by Hearst Communications. The next day, Otto filed suit in federal court for copyright infringement against the companies that used his photograph. Otto reached out of court settlements with all of the organizations except Hearst. On January 18, 2019 the court held that a media outlet cannot take a photograph from a social media platform, publish it, and avoid paying the photographer for a license to do so. The ruling has significant ramifications for media companies and artists alike.

This article discusses the court's legal analysis, which focused on evaluating Hearst's defense of fair use. Under U.S. copyright law, fair use enables someone other than the original author to use a work to create a new work. Fair use has also been held to allow the public's interest in newsworthy events to prevail over the copyright owner's exclusive right to control the work. In this case, the court found that Hearst had published the image without adding "new information, new aesthetics, new insights and understandings." While Esquire included a brief news article with the photograph, it was little more than a description of the image and the location where it was taken. The court found that when Otto sent his photo to Burke, he neither waived his copyright nor consented to the image being posted on social media and then picked up by Hearst. The court held that no reasonable jury could find that Otto's sending the image to Burke without explicit restrictions constituted a license of Burke to use the image. Moreover, the court found that even if Otto had intended to allow Burke to distribute the image, such permission did not extend to Hearst. Finally, the court held that because a jury could differ on whether Hearst's infringement was willful—allowing for damages up to $\$ 150,000-$ Hearst's motion that it did not act willfully had to be denied. Therefore, the case will continue towards trial, with several key issues decided in Otto's favor.

Keywords: fair use, Otto v. Hearst Publications, Hearst, Esquire, Donald Trump

Vincent Peppe is an entertainment and intellectual property attorney and the founder of Copyright Recapture Group. Peppe has over twenty-five years' experience handling transactions and disputes involving business, entertainment, and technology. He has held positions as Director \& Counsel for Internet \& New Media at SESAC and as General Counsel at Naxos, the world's leading classical music label. He also served as Vice President for Digital Distribution at GameZnFlix, where he developed one of the first subscription services for delivering movies to computers and mobile devices. Vincent is a graduate of the New England Conservatory of Music and Brooklyn Law School where he was an editor of the Brooklyn Law Review. He is the recipient of the ASCAP Nathan Burkan Award for excellence in copyright law. He is licensed to practice law in Tennessee, New York, and Connecticut.

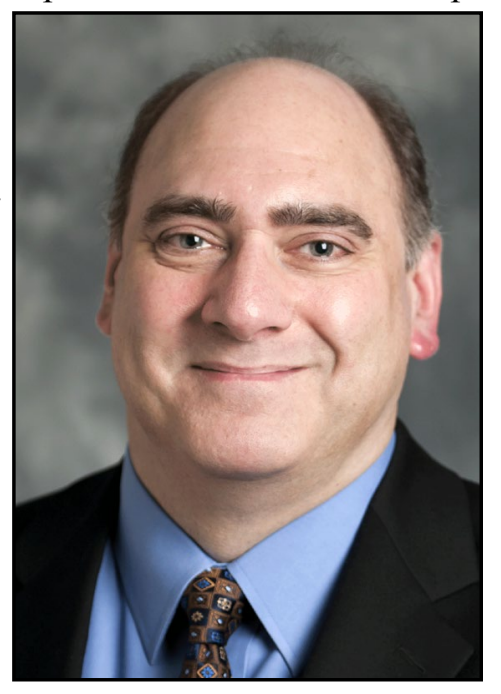




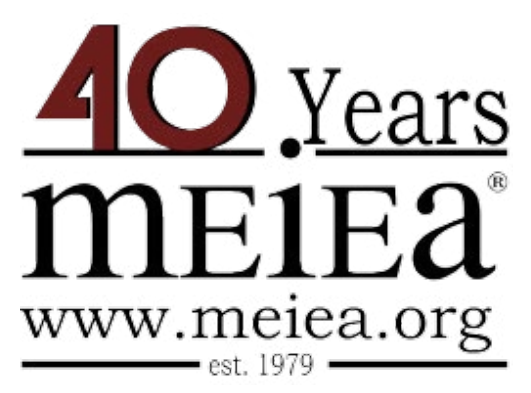

\section{PROCEEDINGS OF THE \\ 2019 INTERNATIONAL SUMMIT \\ OF THE \\ MUSIC \& ENTERTAINMENT \\ INDUSTRY EDUCATORS \\ ASSOCIATION}

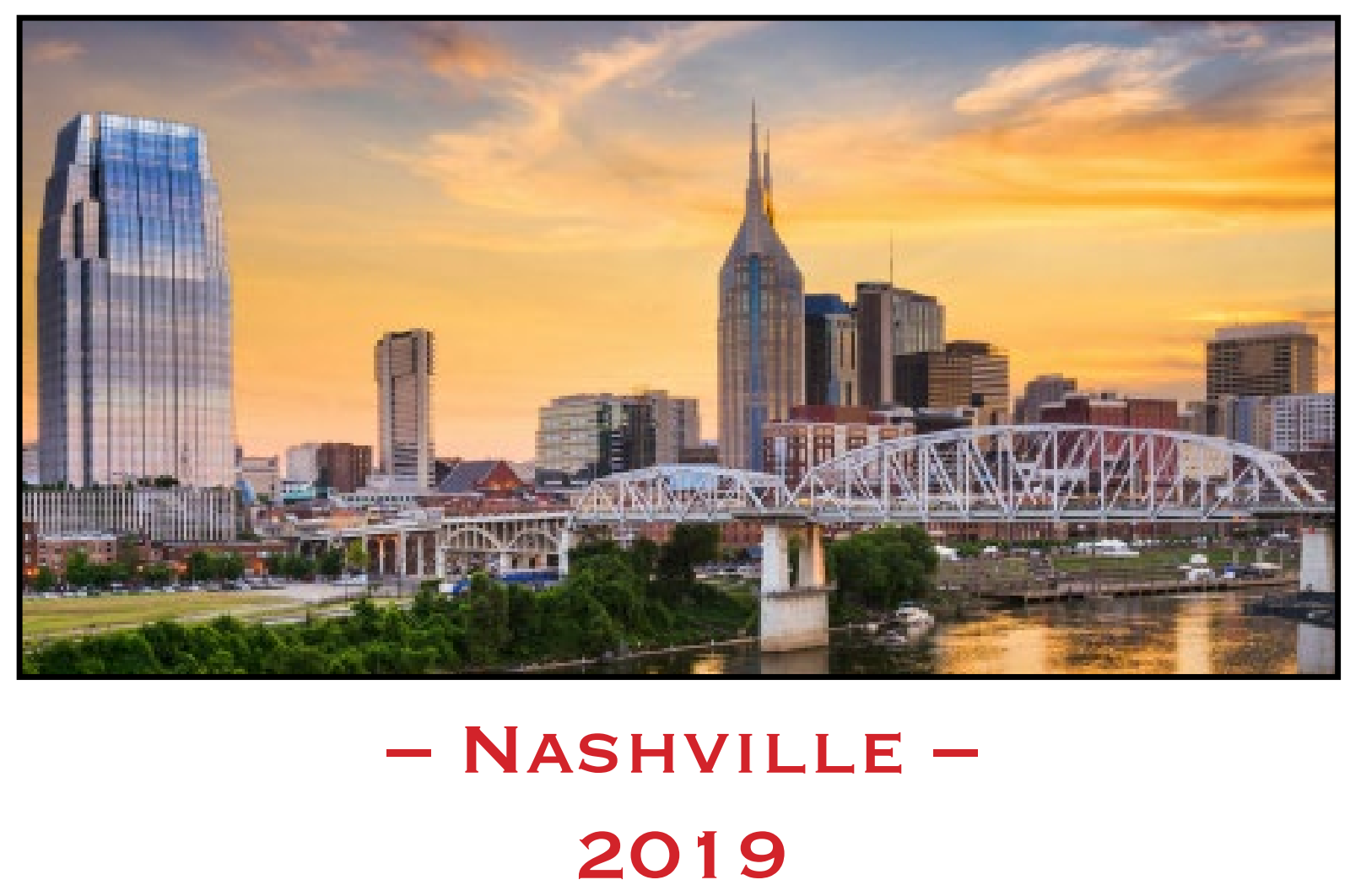

March 21 - 23, $2019 \cdot$ Belmont University - Nashville 